Vol. 1, No.1, PP. 25-32, 2016

Received on: 30.11.2016

Revised on: 20.12.2016

www.ijoaem.com

\title{
The Psychology of the Successful Entrepreneur
}

\author{
Authors: $\quad$ Kaushal Mukherjee \\ Dept. of ECE, Bankura Unnayani Institute of Engineering, Bankura, 722146, India \\ e-mail:mukherjeek95@gmail.com
}

Subject Category: Management

Sub Category: Entrepreneursship

Editor:

Janmoni Borah

Volume 1 Issue 1 December 2016

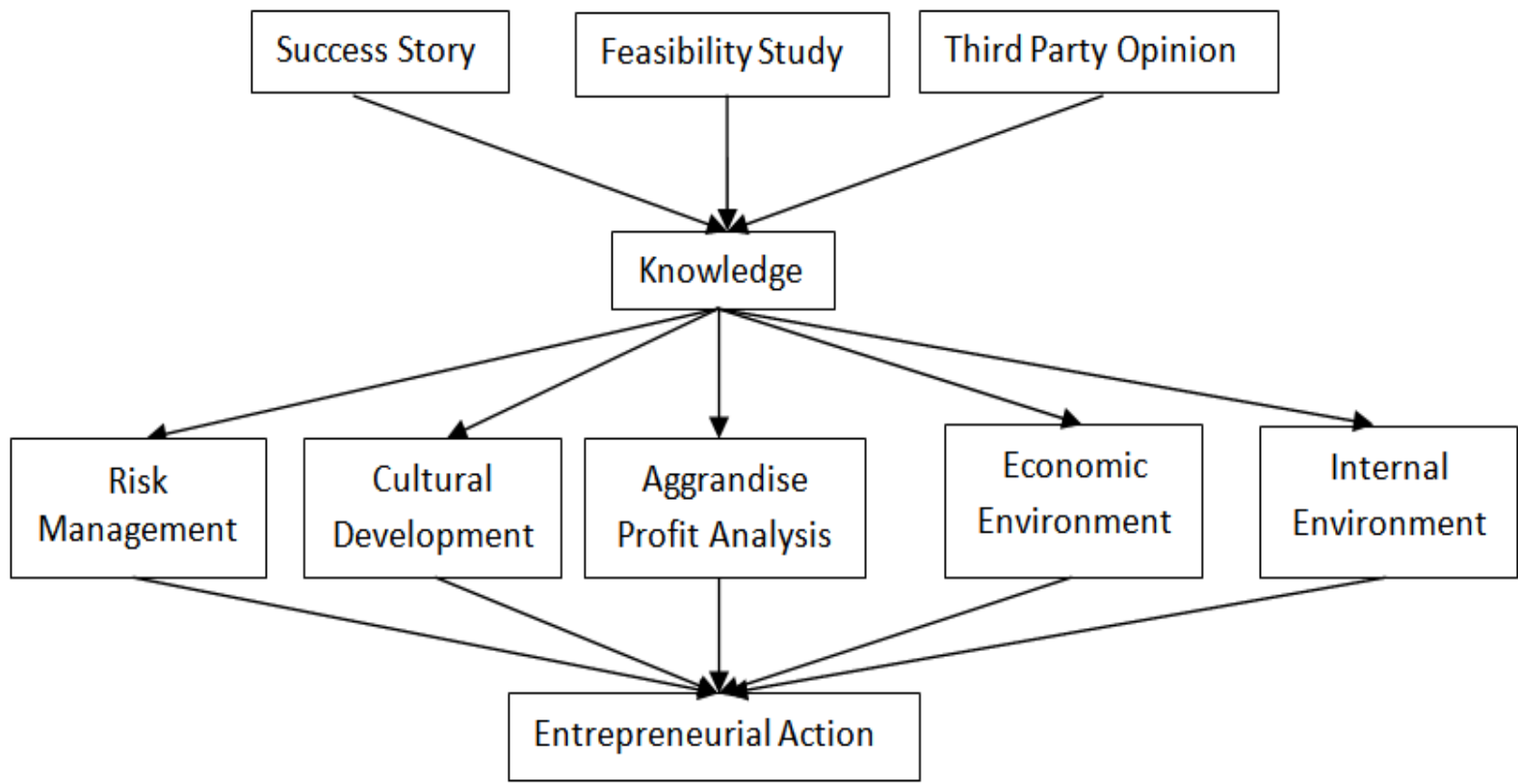

Illustration of entrepreneurial action plan.

Keywords: $\quad$ Employee participation;

Entrepreneurialism;

Entrepreneurial action plan;

Psychology of the successful entrepreneur;

Workplace learning. 


\title{
The Psychology of the Successful Entrepreneur
}

\author{
Kaushal Mukherjee
}

\begin{abstract}
The entrepreneurship development is mainly due to the entrepreneurial motivation. The motivation of entrepreneurs is influenced by the external as well as internal environmental factors. Though there is no research study which reveals the extent to which the entrepreneurs are motivated by these two environments it is found that the entrepreneurial motivation is due to the influence of both the external and internal environmental factors. The psychological behaviours of the entrepreneurs are also equal playing its role while motivating the entrepreneurs, which are also discussed here. This paper also helps entrepreneurs to identify the different business opportunities and growth of the existing business. A real entrepreneur is a person who generally motivated by intrinsic psychological and also economic rewards. He indigenously tries an entrepreneurial venture for his personal satisfaction in work, ego or status. This paper reviews the psychological literature on entrepreneurs. Assessment and generalizations for the entrepreneurs are risky since there is no specific population of entrepreneurs. Psychological characteristics: In the modem days a suitable entrepreneurial culture must be created by developing healthy work environment and modem attitude towards work giving social recognition etc. These factors will provide the psychological stimulus which in turn promotes innovation, inspiration, ethics and values which are essential for successful entrepreneurs. The irrational behaviours of the entrepreneurs are also playing a vital role while motivating the entrepreneurs.
\end{abstract}

\section{Introduction}

Entrepreneurs are not always a born genius. Through systematic and rigorous training, entrepreneurs can be made. Young entrepreneurs have little knowledge on management, production process and marketing. Lack of proper training prevents people to become entrepreneurs [1]. Otherwise, they could come forward to make use of the emerging opportunities that are emanating from new technology, new economic policy and from the changing society [2]. Untrained entrepreneurs cannot take right decisions [3]. They may not know the next course of action to be taken soon after the establishment of new business units. With the help of training, they could manufacture right goods at the right time with quality and minimum cost [4]. Training gives confidence to the entrepreneurs and their ability to bear the risks is also getting increased. There is a need to reformulate the existing entrepreneurial development programs that suit to the entrepreneurs of different groups [5]. Entrepreneurs need training at regular intervals so that they could clarify their doubts which many come at every subsequent stages of manufacturing process. Training enable and motivate entrepreneurs to find alternative course, of action to be taken in the event of dearth of funds, poor quality and labour deficiencies. The objectives of training programs must be clear and unambiguous. While selecting for entrepreneurs training, the chance must be given to a group of entrepreneurs whose status, family and social background are uniform [6]. Only the enthused and self-motivated entrepreneurs shall be given chance for undergoing training. The entrepreneurial development programmes become failure due to the wrong choice of selection of entrepreneurs. The entrepreneurial development programs must be such that there must be scope for follow up activities [7]. In other words, the entrepreneurial development and training institutions must give refresher courses and give an opportunity to update the knowledge of entrepreneurs.

Motivation 'is the propelling force for an entrepreneur to predict the future and identify innovative and hitherto unknown business opportunities,. The exhaustion of the existing limited resources motivate entrepreneurs to find alternative resources which are available and unused so far. The scarcity of manual labour compels the entrepreneurs to introduce computers and robots. The growing consumers awareness enable and motivate entrepreneurs to identify their expectations and assess the amount of consumers demand well in advanced and sometimes even before identifying the location of the industry [8]. The new economic policy of the Government

Kaushal Mukherjee, "The Psychology of the Successful Entrepreneur," International Journal of Advanced Engineering and Management, Vol. 1, No. 1, pp. 25-32, 2016. 
motivates entrepreneurs to seek trade and business relations at the global level and motivate them as how best to manufacture quality goods so as to compete in the global market [9]. Similarly, the transfer' of and import of new technology motivate entrepreneurs as how best to adapt the latest technology that must suit to their respective countries.

Under this system both the Government and individual entrepreneurs play an equal role in the entrepreneurship development. The government undertakes those activities which are vital for further economic advancement. In a mixed economy though there are ample opportunities for the entrepreneurship development with the help of the Government support, entrepreneurship development is hindered by the deep-rooted evils like religious conflicts, political instability and unethical practices like smuggling, corruption and adulteration. The need for entrepreneurship development was not felt by the classical economists and the basics are the thought that capital formation led to economic development [10]. Those who have a high level of desire may help them to become successful entrepreneurs which are discussed briefly here. Apart from the psychological and sociological factors, entrepreneurship development is also due to the existing economic activities of the state where the entrepreneurs live. Individuals learn from the current economic events as how best to equip themselves for meeting the future challenges. The rate of economic growth depends upon the number of innovations introduced by the entrepreneurs and the extent with which the financial institutions come forward to finance the new venture businesses which are associated with high risks. It is better to considered the fact that, the prevailing entrepreneurship development determines the economic growth and innovation itself is of no use unless it is made available to the public through new product and the activities involved in such processes are called as 'entrepreneurship' which are discussed in this paper.

\section{Psychology of the Entrepreneur}

In the dynamic society, the entrepreneurs foresee the future and smell the undesirable consequences well in advance. Predicting the future with all accuracy is the first step for a successful entrepreneur. Entrepreneurs identify the business opportunities. Entrepreneurial motivation is also due to entrepreneur's mental ability to bear the risks and his capacity to calculate the risks. Successful entrepreneurs are ready to bear 'calculated' risks only. In these days risks are being shared. There are mainly three types of psychological characteristics of the entrepreneurs. Effect of previous experience such as bad incident or dissatisfaction in previous jobs can occurred disability in entrepreneurship. Personal characteristics of entrepreneurs: They should well qualified and not much young or highly aged (approx. 25-40).

The following motivational factors that influence entrepreneurs to become successful in their all types of business ventures: (i) demonstration effect, (ii) business background, (iii) technical knowledge, (iv) creating stable market, (v) availability of skilled labor, (vi) ancillarisation, (vii) self determination about the target business, (viii) risk management bearing capacity and (ix) success stories. The establishment of one successful business venture attracts and motivates entrepreneurs to develop and run similar business. Entrepreneurs also learn the demonstration effects through the foreign entrepreneurs.

Entrepreneurs who hailed from the agricultural families are found more successful in their business ventures than those who hailed from business families. Entrepreneurs however they are trained and experienced cannot become successful in their business ventures, unless they rely upon the skilled labour force. Success stories reveal and highlight the circumstances under which successful entrepreneurs started their business ventures. It also highlights the precautions to be taken and the practical difficulties involves in the proposed businesses. The success stories enable entrepreneurs to step into the shoes of the successful businessmen and develop similar business. Success stories of entrepreneurs must be published and screened through various media, very often and in different and in different languages so that there is a chance for new entrants to venture into new business with all vigour. So, developing a program to identify these people and give them counselling and continuous training will help to generate successful entrepreneurs in a large scale.

\section{The Process Model Innovation and Entrepreneurship}

The innovation is a tool of the entrepreneurship, by the mean of which they exploit changes as a chance for a many business and services [11]. The innovation is basically capable of getting learned and capable of being practiced. Entrepreneurship is a man who develops his own business, and that business is new in the market and helpful for the people of society.

Kaushal Mukherjee, "The Psychology of the Successful Entrepreneur," International Journal of Advanced Engineering and Management, Vol. 1, No. 1, pp. 25-32, 2016. 
Now as we know that innovation is a major thing in the entrepreneurship an entrepreneur is the one who implements his idea in the market and makes his company successful and established in the market and they need to apply the innovation in the business for the better improvement. Business is a chance of doing something new in the market, and with the assistant of this, we able to help a lot of people in our society as well as our country.

\section{a) New products}

The most important point in the innovation is to create an entirely new product the new product could be anything can exploit an established technology or it can be an entirely new technology which never has been launched into the market. The new product may pursue in an excellent manner, or it could be the one which is just a modification of the existing product. With the help of new product, we can earn a lot of money as well as we can establish our company.

\section{b) New production techniques}

There is a lot of ways to produce a new technique, and the new technology is the only one who is going to help to be successful entrepreneurs with the aid of new technology we can easily get a better position in the market as well as in any industry. And after this we have to observe the market and the value of our product in the market with the help of this we can say that we can new production technique is critical.

\section{c) Use of innovation in entrepreneurship}

If any product of the company is new, then the company do not have to worry about the market competition. Because the product which they have launched is not there in the market e.g.: when Steve Jobs started personal computers at that time there was no competition in the market, so they got a boost In the market and now they are well known as Apple. Will get a boost in the future: as we already know that who starts the business first will always get a boost in the market. Like as Paytm is the first one which began online recharge through new banking and debit card. Now even if we compare this company from the other company like free recharge and others Paytm is one which is one of the better entrepreneurs in the market.

\section{Characteristics of Entrepreneurship}

Before going into characteristics of entrepreneurship let us know the meaning of an entrepreneur. An entrepreneur is one who sets up a business with a considerable risk. An entrepreneur should have certain qualities or characteristics in him, mainly:

An entrepreneur should be "passionate". He should have that passion to create a business idea and make money by making the idea a great business. Once the idea success he will come into the picture of business magnets which were required his/her idea desperately. The idea which is created can be generated because of existing problem or it can be from his own creation. But creating the idea an entrepreneur should be passionate and enthusiastic.

An entrepreneur should be "self motivated", because an entrepreneur starts business on his own risk, so there will be lot of difficulties ahead of him/her to start his business. To overcome those difficulties he/she should be motivated enough so that their morals cannot drag down. Whatever the problems an entrepreneur should have mental strength to overcome those and become a successful person.

An entrepreneur should have a "versatile" nature. He/her should be changing their attitude so that they can analyze what the situation in business field. There can be a lots of up's and down's in the business or they may need the support of other members, in that situation he/her should be matured enough to handle that situation and making good impression with other members and get support from them. He/her should create such an environment so that everybody will be comfortable with their decisions and work.

An entrepreneur should have "extraordinary business skills". This is an important characteristic of an entrepreneur because he/her initiate the business on its own risk, so they should be perfectionists in business skills, otherwise they would not the outcome what they want and gradually the business going to be failure. To avoiding those disasters they should have great business skills so that they can analyze whether the business going to be success or not, whether the creative idea is required by the public/business firm.

An entrepreneur should be a "risk taker". As we said earlier entrepreneur is someone who start business on his own risk, so he/her they should be mentally prepared for taking risks. If they were not prepared taking the challenges then they will face a lot of troubles, they may lose the chances to become more success. In business world everyday a new change will happen, so entrepreneur will be challenged with the change happened in business, to become more success he/her should take a new step which can make more business than the new thing.

Kaushal Mukherjee, "The Psychology of the Successful Entrepreneur," International Journal of Advanced Engineering and Management, Vol. 1, No. 1, pp. 25-32, 2016. 
An entrepreneur should have the quality "Drive". He/she should drive the company so that the staff follows the lead of him/her. They should become the leader of the firm so that they can show the path to success which can be followed by employee. There should be a proper management by entrepreneur so that the firm cannot face any trouble. So that they should be sit on the first position i.e., driver seat in a vehicle, because wherever he turns the firm moves in that way.

An entrepreneur should have proper "vision". Without proper vision on the business area an entrepreneur cannot become successful [12]. He/she should know the status of the proper field and what is the market of it in society. They should be aware whether the market price will be going down or high or whether the requirement is becoming high in society so that they can change their plans automatically.

If there is no proper vision they will be lost in between the field and they will lag behind the other companies. Not only on a particular field, entrepreneur is also someone who makes the business as per the requirement in the society, so he/she should be aware of what's the things required by the society and what is the market and what is in demand in the society.

An entrepreneur should have the nature "flexibility and open mind". It is the vital role in a firm, when anybody open a firm they should have the open mind, if there is a misunderstanding between the management and employee, then there should be a proper communication between them with open mind, otherwise there will be ethical issues can generate and there would not be a good ease work environment. An entrepreneur should have the flexible nature because if there is a new thing arrives then the company should adapt the change and work that change. If they were unable to follow or utilize the change then the firm will be lag behind the other firms.

An entrepreneur should have the nature "decisiveness". For an entrepreneur there should be no place for procrastination and indecision [13]. He/she should have the mentality to take the decision instantly according to the situation. They should be prepared for the new changes and accordingly for making business they should actively take part in taking decisions without hesitation. When they hesitate to take decision at the proper time they may lose the opportunity which is going to be huge benefit for him/her and the company. So an entrepreneur always is prepared for taking new challenging decisions without any delay.

\section{Entrepreneurial Development Programmes}

There is a need to reformulate the existing entrepreneurial development programs that suit to the entrepreneurs of different groups. Entrepreneurs need training at regular intervals so that they could clarify their doubts which many come at every subsequent stages of manufacturing process. Training enables and motivates entrepreneurs to find alternative course, of action to be taken in the event of dearth of funds, poor quality and labor deficiencies. The objectives of training programs must be clear and unambiguous.

While selecting entrepreneurs for training, chance must be given to a group of entrepreneurs whose status, family and social background are uniform. Only the enthused and self-motivated entrepreneurs shall be given chance for undergoing training. The entrepreneurial development programs become failure due to the wrong choice of selection of entrepreneurs. The entrepreneurial development programs must be such that there must be scope for follow up activities. In other words, the entrepreneurial development and training institutions must give refresher courses and give an opportunity to update the knowledge of entrepreneurs. Illustration of entrepreneurial action plan is shown in Fig. 1.

\section{a) Risk Management}

Entrepreneurial motivation is also due to entrepreneur's mental ability to bear the risks and his capacity to calculate the risks. Successful entrepreneurs are ready to bear 'calculated' risks only. In these days risks are being shared. For instance the raising of capital through equity issue enable entrepreneurs to shift their risks towards the investors. Risks are also shared through collaborative and joint venture agreements.

Entrepreneurs in these days would like to diversify their business mainly with the intention of overcoming the losses. Thus, the opportunity for the avoidance of risks motivates entrepreneurs to take up new business ventures.

\section{b) Cultural Development}

The prevalence of rigid cultural norms and mores act as an impediment for entrepreneurs to introduce innovative businesses. This problem is found more in less developed countries. On the other hand, in the industrially advanced countries existing culture is such that allows people to develop and start any new business. Though the cultural rigidity is an obstacle, entrepreneurs can be motivated to develop new business through cultural liberalization.

Kaushal Mukherjee, "The Psychology of the Successful Entrepreneur," International Journal of Advanced Engineering and Management, Vol. 1, No. 1, pp. 25-32, 2016. 


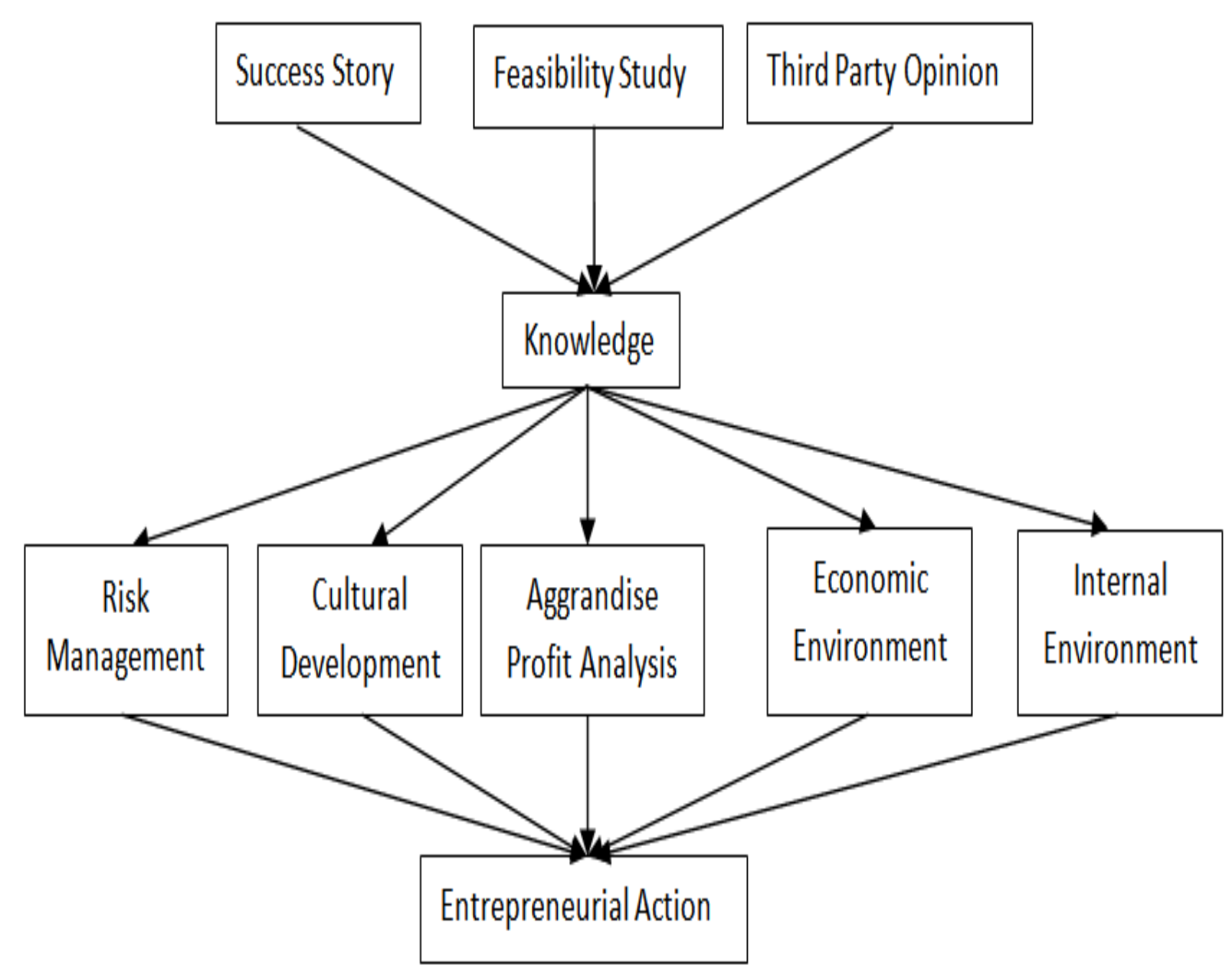

Figure 1. Illustration of entrepreneurial action plan.

\section{c) Aggrandise Profit}

In a true sense, the entrepreneurs are motivated by profit. The expected profit of any new business ventures is always high. Since there is little competition at the initial stage of business entrepreneurs are motivated to introduce new business and earn the maximum profit until other competitors enter into their lines of businesses. Entrepreneurs in Japan follow this practice.

Though they import technology, they adapt and manufacture new lines of goods and earn high rate of profit. As soon as they face competition, they give away their existing business and try to establish a new one.

Thus, entrepreneurs are motivated to introduce new business mainly due to the chance for earning a high rate of profit.

\section{d) Economic Environment}

The changing economic environment acts as a motivating factor for entrepreneurs to think of new business developments. The policy of liberalisation enable Government to invite NRI investors and allow them to establish infrastructure supporting industries like generation of power, communication equipments etc., The free exports and imports motivate entrepreneurs to find a new for their goods at the international market.

The development of private large scale industry would pave way for ancillarisation and there is a vast scope for the growth of SSI units. The globalisation of the business sector enables entrepreneurs to mobilize the latest talents and thereby develop new business.

Kaushal Mukherjee, "The Psychology of the Successful Entrepreneur," International Journal of Advanced 


\section{e) Internal Environment}

Apart from the above said external environmental factors, the entrepreneurs' motivation also depends upon the internal environment viz., the family background of the entrepreneurs that is weather they hail from the agricultural family or business family, the professional and academic achievements of the entrepreneurs, the level of education, training acquired, their previous experiences and their mental behaviors. Besides, the personality development, leadership qualities and ability to achieve character of the entrepreneurs also act as congenial climate for entrepreneurs to enter into new business ventures.

Though there are many environmental factors, all entrepreneurs are not motivated by all the factors or a group of similar factors. No research study has so far been found and undertaken to prove the fact that what environmental factors that exactly motivate entrepreneurs and in what proportion. Again there is no adequate literature found available as when the motivation works in the mind of entrepreneurs. However, one would say that behind every successful entrepreneur there is at least one motivational factor that strongly influences him to become a successful entrepreneur.

The entrepreneurs must have some inborn skills which intern motivate entrepreneurs to establish new business. Thus, motivation is like a foundation with which the entrepreneurs build new business, and it is the intensity of motivation that determines the height of success of new business ventures. Let us see the various factors that motivate entrepreneurs to play their role and thereby see how far motivation helps to build entrepreneurship development.

\section{Conclusion}

In this paper vividly explains the need and importance of entrepreneurship, the different stages in the process of entrepreneurship development and various strategies of identifying and promoting entrepreneurship. It is understood from the previous discussion that entrepreneurship development is due to the entrepreneurial role played by the entrepreneurs and in the Government. The role of entrepreneurs is a continuous phenomenon. In the dynamic society, the entrepreneurs foresee the future and smell the undesirable consequences well in advance. Predicting the future with all accuracy is the first step for a successful entrepreneur. Entrepreneurship development depends upon the prevailing economic system. The entrepreneurship development is mainly due to the existence of such economic system. It is the entrepreneurship development that acts as a fillip to new, structure of the economy and economic reforms too. Persons who pose psychological urge can able to achieve something new.

\section{References}

[1] J. W. Carland, F. Hoy and J. A. C. Carland, "Who is an Entrepreneur? Is a Question Worth Asking," American Journal of Small Business, vol. 12, no. 4, pp. 33-39, 1988.

[2] B. Ä. Lundvall and B. Johnson, "The Learning Economy," Journal of Industry Studies, vol. 1, no. 2, pp. 2342, 1994.

[3] M. Macovei, "The Austrian Business Cycle Theory: A Defense of Its General Validity," Quarterly Journal of Austrian Economics, vol. 18, no. 4, pp. 409-435, 2015.

[4] Y. L. Doz and K. Mikko, "Embedding Strategic Agility: A Leadership Agenda for Accelerating Business Model Renewal," Long Range Planning, vol. 43, no. 2, pp. 370-382, 2010.

[5] R. A. Burgelman, "Designs for Corporate Entrepreneurship in Established Firms," California Management Review, vol. 26, no. 3, pp. 154-166, 1984.

[6] E. Hamilton, "Entrepreneurial Learning in Family Business: A Situated Learning Perspective," Journal of Small Business and Enterprise Development, vol. 18, no. 1, pp. 8-26, 2011.

[7] B. Klinger and M. Schündeln, "Can Entrepreneurial Activity be Taught? Quasi-Experimental Evidence From Central America," World Development, vol. 39, no. 9, pp. 1592-1610, 2011.

[8] J. J. Wang, X. Zhao and J. J. Li, "Group Buying: A Strategic Form of Consumer Collective," Journal of Retailing, vol. 89, no. 3, pp. 338-351, 2013.

[9] J. W. Webb, G. D. Bruton, L. Tihanyi and R. D. Ireland, "Research on Entrepreneurship in the Informal Eeconomy: Framing a Research Agenda," Journal of Business Venturing, vol. 28, no. 5, pp. 598-614, 2013.

[10] J. Foster and J. S. Metcalfe, "Economic Emergence: An Evolutionary Economic Perspective," Journal of Economic Behavior \& Organization, vol. 82, no. 2, pp. 420-432, 2012.

[11] B. Johannisson, "Business formation-a network approach," Scandinavian Journal of Management, vol. 4,

Kaushal Mukherjee, "The Psychology of the Successful Entrepreneur," International Journal of Advanced 
no. 3-4, pp. 83-99, 1988.

[12] R. D. Hisrich, “Entrepreneurship/ Intrapreneurship,” American Psychologist, vol. 45, no. 2, pp. 209-222, 1990.

[13] J. S. McMullen and D. A. Shepherd, "Entrepreneurial Action and the Role of Uncertainty in the Theory of the Entrepreneur," Academy of Management Review, vol. 31, no. 1, pp. 132-152, 2006. 